\title{
Penilaian Zona Kerentanan Air Tanah Terhadap Pencemaran dengan Metode SINTACS di Ranai (Pulau Bunguran)
}

\section{Assessment of Groundwater Vulnerability Zones to Pollution Using the SINTACS Method in Ranai (Bunguran Island)}

\section{Erik Febriarta ${ }^{1}$}

Magister Pengelolaan Pesisir dan Daerah Aliran Sungai

Fakultas Geografi, Universitas Gadjah Mada, Yogyakarta, Indonesia

\section{Dian Indah Shofarini}

Jurusan Perencanaan Wilayah dan Kota, Fakultas Teknik

Universitas Brawijaya, Malang, Indonesia

Artikel Masuk : 1 Desember 2020

Artikel Diterima : 8 Februari 2021

Tersedia Online : 30 April 2021

\begin{abstract}
Abstrak: Pulau Bunguran Besar di Kepulauan Natuna Provinsi Kepulauan Riau didominasi oleh topografi dataran rendah dengan kondisi morfologi kemiringan landai hingga curam. Secara umum dataran di Pulau Bunguran besar memiliki topografi dataran dengan ketinggian tempat berkisar 5- 30 mdpal dan ketinggian tempat tertinggi berada di Gunung Ranai 920 mdpal. Kondisi tersebut mengakibatkan permasalahan lingkungan terutama pada dataran terbentuk cekungan dengan genangan yang mempengaruhi kondisi sumber daya air tanah yang mudah tercemar yang dipengaruhi oleh keterdapatan air tanah (akuifer) yang dangkal dan dekat dengan permukaan. Kondisi akuifer yang dangkal dan relatif dekat dengan permukaan memiliki potensi pencemaran air tanah oleh sumber pencemar. Penelitian ini bertujuan untuk mengidentifikasi potensi pencemaran air tanah secara keruangan (spasial) dengan pendekatan hidrogeologi metode SINTACS. Metode SINTACS merupakan pendekatan kerentanan dengan pemberian nilai dan bobot dari setiap parameter atau dapat memicu terjadinya kerentanan. Data primer yang digunakan untuk penilaian kerentanan yaitu kedalaman freatik air tanah, tekstur tanah, dan kemiringan lereng. Sedangkan parameter kondisi infiltrasi, kondisi aerasi pada batuan, penysusun batuan (litologi) akuifer, dan nilai konduktivitas hidrolik (K) atau kelulusan air pada batuan diperoleh dari pendekatan data sekunder. Sekenario kerentanan pencemaran air tanah mengunakan pendekatan dampak skenario normal. Diketahui bahwa kondisi kerentanan rendah $28 \%$ atau seluas $486 \mathrm{~km}^{2}$, kerentanan sedang $20 \%$ atau seluas $343,8 \mathrm{~km}^{2}$, kerentanan tinggi $0,04 \%$ atau seluas $0,7 \mathrm{~km}^{2}$ dan kerentanan sangat tinggi $52 \%$ atau seluas $898,7 \mathrm{~km}^{2}$. Secara umum kondisi kerentanan di Pulau Bunguran Besar sangat tinggi.
\end{abstract}

Kata Kunci: air tanah; kerentanan; keruangan; pencemaran; SINTACS

\footnotetext{
Korespondensi Penulis: Magister Pengelolaan Pesisir dan Daerah Aliran Sungai, Fakultas Geografi Universitas Gadjah Mada, Yogyakarta, Indonesia

Email: ricohottetra@gmail.com
} 


\title{
35 Penilaian Zona Kerentanan Air Tanah Terhadap Pencemaran dengan Metode SINTACS...
}

\begin{abstract}
Bunguran Besar Island in the Natuna Islands, Riau Islands Province, is dominated by a lowland topography with a sloping to steep morphological condition. In general, the plains on the island of Bunguran Besar have a plains topography with altitudes ranging from 5- 30 meters above sea level, and the highest altitude is on Mount Ranai, 920 meters above sea level. This condition causes environmental problems, especially on the plains that form basins with geodes that affect the condition of easily polluted groundwater resources influenced by the presence of shallow and close to the surface groundwater (aquifer). The condition of the aquifer, which is shallow and relatively close to the surface, has the potential for groundwater contamination by polluting sources. This study aims to determine the potential spatial groundwater pollution using the SINTACS method hydrogeological approach based on this background. The SINTACS method is a vulnerability approach by assigning a value and weight to each parameter or triggering the vulnerability. The primary data used for the vulnerability assessment were phreatic groundwater depth, soil texture, and slope. Meanwhile, the parameters of the infiltration conditions, the aeration conditions of the rocks, the compiler of lithology, and the hydraulic conductivity $(K)$ or the passing of water in the rock were obtained from the secondary data approach. The scenario of groundwater pollution vulnerability uses the normal scenario impact approach. It is known that the condition of low vulnerability is $28 \%$ or an area of $486 \mathrm{~km}^{2}$, medium vulnerability is $20 \%$ or an area of 343.8 $\mathrm{km}^{2}$, high vulnerability is $0.04 \%$ or an area of $0.7 \mathrm{~km}^{2}$, and very high vulnerability is $52 \%$ or an area of $898.7 \mathrm{~km}^{2}$. In general, the condition of vulnerability in Bunguran Besar Island is very high.
\end{abstract}

Keywords: groundwater; pollution; spatial; SINTACS; vulnerability

\section{Pendahuluan}

Kebutuhan air bersih merupakan kebutuhan dasar manusia dan makhluk hidup di sekitarnya. Definisi air menurut BSN (2002) merupakan semua air yang terdapat di dalam tanah (bawah permukaan) dan berasal dari sumber-sumber air, baik yang terdapat di atas maupun di bawah permukaan tanah, tidak termasuk dalam pengertian air yang terdapat di laut. Sedangkan, air bawah tanah (air tanah) merupakan semua air yang terdapat dalam lapisan atau batuan di bawah permukaan tanah pada kondisi zona jenuh air (BSN, 2005). Sumber daya air yang dapat dimanfaatkan dalam skala besar adalah bersumber dari air tanah (potensi air bawah tanah), hal tersebut dipengaruhi oleh sifat keterusan air tanah. Parameter akuifer berupa keterusan atau transmitivitas $(\mathrm{T})$ merupakan jumlah air yang dapat mengalir melalui suatu bidang vertikal setebal akuifer dalam satuan panjang dengan landaian hidrolik yang dinyatakan dengan satuan $\mathrm{m}^{2}$ /hari (BSN, 2005; Todd \& Mays, 2005). Salah satu cara dalam pemanfaatan sumber daya tersebut dapat diperoleh dari eksplorasi air tanah dari bawah permukaan tanah (seperti sumur gali atau sumur bor). Sumber daya air di wilayah kepulauan sangat dipengaruhi oleh kondisi iklim, salah satunya adalah kondisi curah hujan (DPU, 2006; Febriarta et al., 2015, 2018). Sumber daya air sangat dipengaruhi oleh kondisi curah hujan, kondisi tersebut merupakan imbuhan atau pasokan air di suatu wilayah yang kemudian sebagian tersimpan di dalam bawah permukaan dan menjadi air tanah (akuifer) (Febriarta \& Oktama, 2020; Purnama et al., 2019).

Keterdapatan air tanah sangat dipengaruhi oleh sifat hidrologi batuan dalam kapasitas menyimpan air tanah dalam media rongga antar butir atau celah (Fetter, 2014). Potensi atau kemampuan batuan dalam menyimpan air tanah disebut dengan porositas efektif (sy). Porositas efektif (sy) dengan nilai yang besar $>80 \%$ mempunyai potensi air tanah yang sangat besar seperti pada penyusun batuan dengan ukuran butir sedang hingga kasar seperti kerakal, pasir kasar maupun batu gamping bercelah. Sebaliknya, nilai porositas efektif yang semakin kecil mempunyai potensi air tanah yang rendah, terbatas hingga nihil, seperti endapan lanau dan lempung (Febriarta \& Larasati, 2020; Febriarta., 2020; Fetter, 2014; Singhal \& Gupta, 2010). Karakteristik kepulauan struktural dengan 
formasi material penyusun dari rombakan lereng berupa material endapan lepas-lepas seperti pada karakteristik kepulauan struktural di Kepulauan Karimata (Febriarta et al., 2018). Pada daerah cekungan (lembah) dapat membentuk zona air tanah dangkal dengan kontak langsung dengan daerah permukaan, sehingga dapat menjadi salah satu pendorong faktor pencemaran apabila terkontaminasi oleh sumber pencemar (polutan) dalam waktu yang lama. Sumber pencemar dapat berasal dari limbah domestik atau kegiatan rumah tangga, seperti: sampah rumah tangga, sisa sabun dari mencuci, dan limbah sanitasi (DPU, 2006; Putranto \& Rüde, 2016; Sugianti et al., 2016).

Pulau kecil (kepulauan) menurut Cahyadi (2019) memiliki karakteristik kerentanan yang lebih tinggi yang dipengaruhi oleh faktor batuan (geologi) dengan sifat mengalirkan air secara cepat dan curah hujan yang tinggi yang mengakibatkan pengenceran sumber pencemar (polutan). Febriarta \& Vienastra (2020) menyebutkan bahwa pulau kecil dengan kondisi morfologi datar hingga bergelombang memliki potensi membentuk cekungan yang mengakibatkan daerah tersebut rentan terhadap pencemaran. Kondisi tersebut memiliki kemiripan lingkungan di Kepulauan Natuna yang memiliki daerah yang relatif datar dan banyak terdapat cekungan berupa genangan dan rawa (BIG, 2018b). Kondisi geologi regional di Pulau Bunguran Besar atau di Kepulauan Natuna memiliki struktur utama yang dominan berupa sesar dan lipatan. Terdapat sesar geser di bagian tengah pulau (Gambar 1) yang merupakan kenampakan struktur yang paling menonjol di Pulau Bunguran Besar. Sesar atau patahan normal membentang dengan arat baratlaut-tenggara. Sisa antiklin atau puncak perbukitan dengan arah sumbu utara-baratlaut terdapat pada Formasi Pengadah (batu konglomerat, batupasir dan lanau). Sumbu arah struktur tersebut terletak kurang lebih disepanjang Sungai Mara. Sayap sebelah barat membentuk homoklinal dengan kemiringan berkisar anatra $10^{\circ}$ dan $20^{\circ}$ kearah barat, sedangkan sayap timur telah tererosi. Kondisi tersebut mengakibatkan sifat aliran air dikontrol oleh faktor geologi.

Formasi penyusun batuan di Pulau Bunguran Besar terdiri atas Formasi Aluvium (Qa) yang tersusun atas batuan kerikil, lanau dan gambut, Formasi Raharjapura (Tpr), yang tersusu atas selang-seling batupasir dan batulanau, Formasi Pengadah yang tersusun atas batu konglomerat, batupasir dan batulanau, Formasi Granit Ranai (Kgr) yang tersusun atas batu granit, putih kotor, porfiritik, holokristalin, kuarsa, ortoklas, plagioklas, biotit dan muskovit, Formasi Bunguran ( Jkb) yang tersusun atas perselingan batulanau, tuf dan rijang dan Formasi Batuan Mafik/Ultramafik (Jum) yang tersusun atas batu peridotit, gabro dan basal (Hakim \& Suryono, 1994). Kondisi batuan tersebut, menurut (Gunawan et al., 2013) yang didominasi oleh material lepas memicu terjadainya pencemaran air tanah. Kondisi geologi regional di Pulau Bunguran Besar disajikan pada Gambar 1. Secara umum distribusi keruangan (spasial) penyusun batuan di Pulau Bunguran Besar didominasi oleh batuan batupasir dan lanau, dan formasi batuan yang mendominasi adalah Formasi Raharjapura (Tpr) atau seluas $49,7 \%$ dari luas wilayah.

Keterdapatan air sangat dipengaruhi oleh kondisi hidrogeologi. Hidrogelogi merupakan kondisi keterdapatan air tanah pada formasi batuan (kondisi geologi regional). Menurut (Hakim \& Suryono, 1994) kondisi morfologi di Pulau Bunguran Besar didominasi oleh kemiringan lereng landai. Berdasarkan kondisi tersebut, terdistribusi merata berupa endapan sedimen lempung pasiran. Karakteristik litologi (penyusun batuan) akuifer tersusun atas tiga kelompok batuan, yaitu endapan lepas, batuan padu dan batu malihan dan beku. Produktivitas akuifer terdiri atas tiga kondisi, yaitu produktivitas sedang yang terdapat pada bagian barat dan selatan pulau, produktivitas kecil setempat berarti yang terdistribusi hampir diseluruh pulau dan produktivitas air tanah langka (KESDM, 2015b). Secara umum di Pulau Bunguran Besar tidak termasuk bagian dari cekungan air tanah (CAT), tetapi termasuk ke dalam karakteristik keterdapatan air tanah dengan penyebaran luas, dan dangkal (BIG, 2018b; KESDM, 2012, 2015b, 2018; Pemerintah Republik Indonesia, 2017). 


\section{Penilaian Zona Kerentanan Air Tanah Terhadap Pencemaran dengan Metode SINTACS...}

Produktivitas air tanah sedang memiliki karakteristik penyebaran luas, media akuifer ruang antar butir, dan keterusan sedang. Kondisi tersebut berada pada formasi batuan yang tersusun atas aluvium. Produktivitas kecil setempat berarti memiliki karakteristik akuifer bercelah atau sarang, dengan keterusan rendah dan debit kecil hingga langka (Febriarta \& Larasati, 2020; Todd \& Mays, 2005). Kondisi produktivitas kecil terdistribusi seluas 52\% dari luas wilayah (Gambar 2). Produktivitas air tanah langka terdapat pada kondisi topografi berbukit dengan kondisi topografi 300-9210 mdpal seperti pada Gunung Ranai (921 mdpal). Produktivitas langka secara keruangan (spasial) terdapat pada bagian tengah dan selatan pulau Produktivitas air tanah langka terdapat pada penyusun batuan berupa batuan padu dan malihan-beku, antara lain, batuan konglomerat, batupasir, batulanau, perselingan lanau, tuf dan rijang. Secara spasial kondisi produktivitas air tanah disajikan pada Gambar 2.

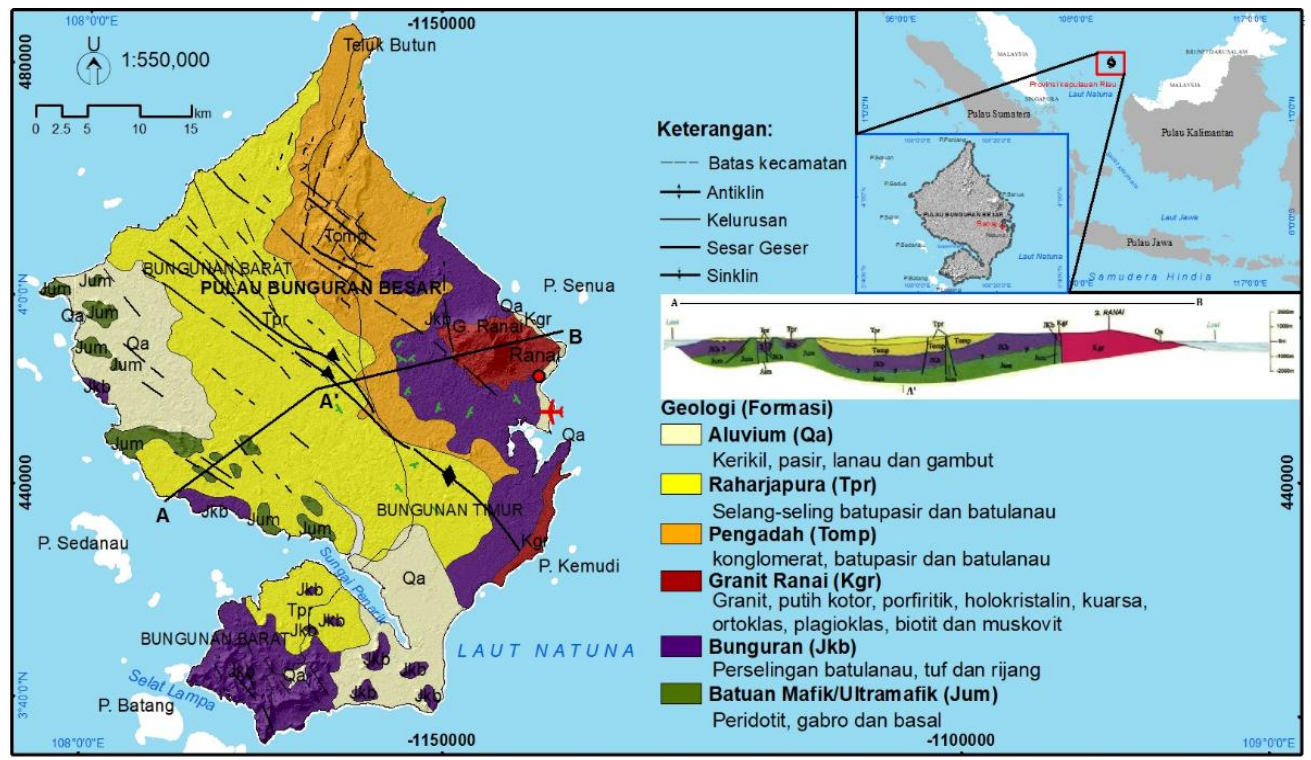

Sumber: KESDM, 2012; Hakim \& Suryono, 1994

\section{Gambar 1. Geologi Regional Pulau Bunguran Besar}

Karakteristik kepulauan dengan topografi dataran rendah memiliki permasalahan lingkungan dari kondisi aliran permukaan yang relatif mudah tergenang. Akibat terbentuknya genangan secara berkala, genangan dapat terinfiltrasi masuk kedalam akuifer pada kondisi kedalaman akuifer yang dangkal. Hal tersebut mengakibatkan sistem akuifer mudah tercemar dari sumber pencemar (polutan) (Cahyadi, 2019; Devianto et al., 2019; Putranto \& Rüde, 2016; Vienastra \& Febriarta, 2018). Kota Ranai merupakan Pusat Kegiatan Strategis Nasional (PKSN) yang berfungsi sebagai kawasan perkotaan untuk pengembangan kawasan perbatasan negara (Pemerintah Republik Indonesia, 2020). Pentingnya Kota Ranai sebagai PKSN, maka diperlukan informasi dasar untuk mengambil keputusan terutama kebijakan dalam pengelolaan perlindungan lingkungan hidup. Salah satunya adalah adanya ketersediaan infromasi rencana pengelolaan sumber daya yang disebutkan dalam Undang-Undang (UU) nomor 32 tahun 2009. Inventarisasi kondisi lingkungan dan ketersediaan data spasial merupakan salah satu langkah dalam percepatan pembangunan (BIG, 2018b; Pemerintah Republik Indonesia, 2020). Upaya pengelolaan dan perlindungan sumber daya, salah satunya adalah penyediaan informasi potensi pencemaran air tanah (BIG, 2018b; Febriarta \& Oktama, 2020; Harter \& Walker, 2001; Lathamani et al., 2015; Putranto et al., 2020). 


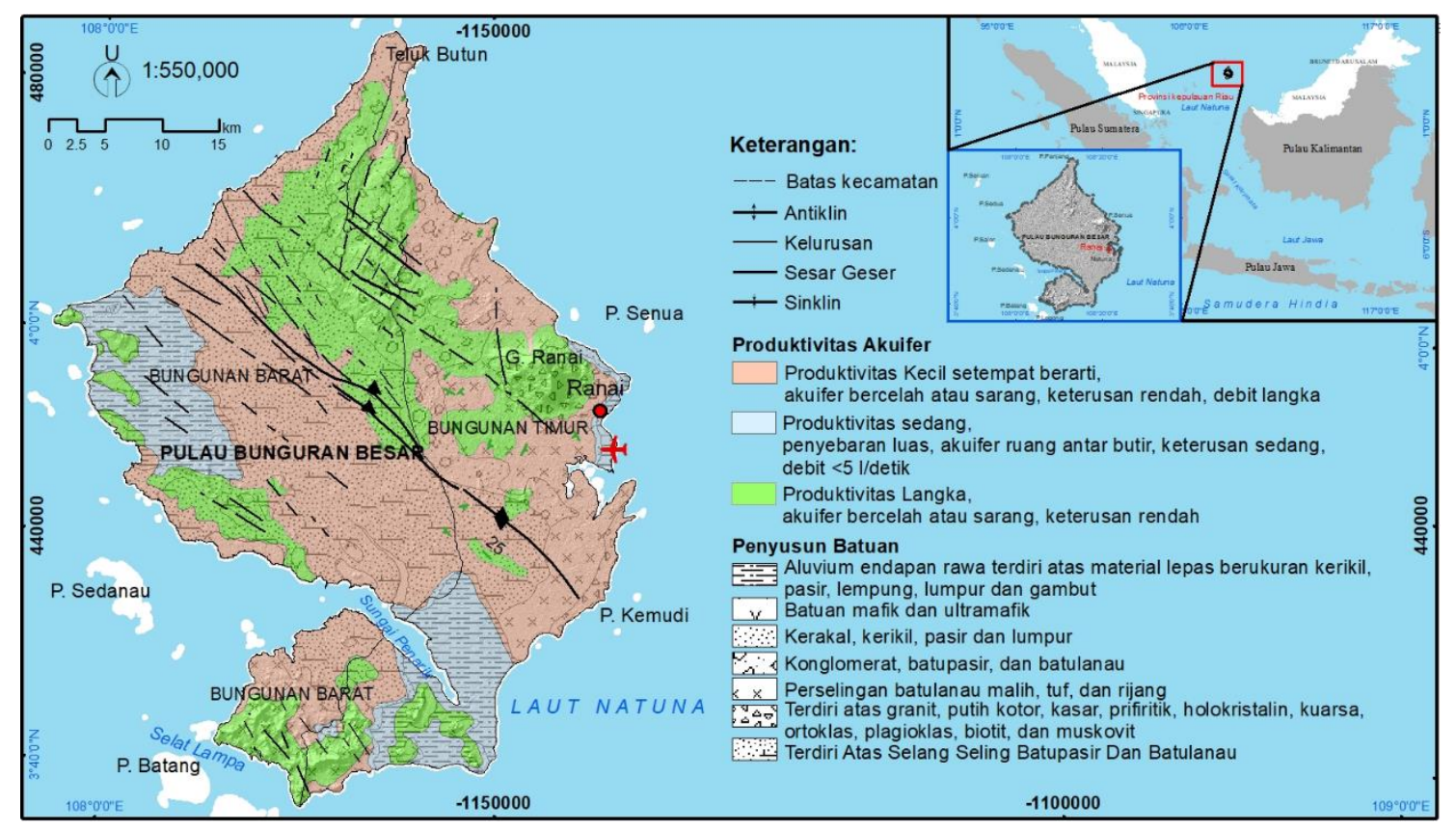

Sumber: KESDM, 2012, 2015b, 2015a

\section{Gambar 2. Kondisi Hidrogeologi Pulau Bunguran Besar}

Kerentanan air tanah tidak dapat diidentifikasikan secara langsung di lapangan (Cahyadi, 2019). Kerentanan air tanah tehadap pencemaran dapat dimodelkan dengan pendekatan kompilasi informasi tentang parameter akuifer (Thapa et al., 2018; Voutchkova et al., 2021; Vrba \& Zaporozec, 1994). Pendekatan penilaian kerentanan tanah dikembangkan oleh Foster (1987) dengan metode GOD merupakan analisis sederhana didasarkan atas tiga parameter, yaitu tipe akuifer, litologi akuifer dan kedalaman akuifer. Metode GOD belum dapat menyajikan zona dengan fokus risiko pencemaran (Linggasari et al., 2019). Perkembangan kerentanan dengan multi kriteria parameter memicu terjadinya kerentanan dengan mempertimbangkan kondisi tekstur pemukaan tanah dengan laju infiltrasi seperti yang dikembangkan oleh Ferreira et al. (2004) dengan metode SEEPAGE (Appelo \& Postma, 2007; Ferreira et al., 2004; Putranto et al., 2016). Kedua metode tersebut didasarkan atas kondisi statis kapasitas secara geologi, tetapi belum mempertimbangkan laju percepatan pencemaran dari sifat parameter akuifer (Febriarta \& Oktama, 2020; Marfai et al., 2020; Voutchkova et al., 2021). Oleh karena itu, penelitian ini berfokus pada penilaian kerentanan air tanah dengan mempertimbangan sifat hidrogeologis dan sifat fisik tanah permukaan yang memengaruhi laju percepatan masuknya sumber pencemar (polutan) masuk ke dalam akuifer dengan metode SINTACS. Penelitian ini bertujuan untuk mengidentifikasi potensi pencemaran air tanah secara keruangan (spasial) dengan pendekatan hidrogeologi pada air tanah (akuifer) yang dangkal dan dekat dengan permukaan di Pulau Bunguran Besar, Kabupaten Natuna, Provinsi Kepulauan Riau.

\section{Metode Penelitian}

Lokasi kajian zona kerentanan air tanah terhadap pencemaran secara geografis terletak di $4^{\circ} 15^{\prime} 31.18^{\prime \prime} \mathrm{LU}$ dan $107^{\circ} 57^{\prime} 40.36 " \mathrm{BT}$ - $3^{\circ} 36^{\prime} 21.41^{\prime \prime} \mathrm{LU}$ dan 108 $24^{\prime} 52.61^{\prime \prime B T}$. Secara administrasi berada di Pulau Bunguran Besar, Kabupaten Natuna, Provinsi Kepulauan Riau. Bagian utara berbatasan dengan Pulau Sekatung dan Laut Natuna, bagian 
barat berbatasan dengan kepulauan Natunan dan Laut Natuna Utara, bagian selatan berbatasan dengan Laut Natuna dan bagian timur berbatasan dengan Laut Natuna.

Penelitian ini menggunakan data primer dan data sekunder dalam pengolahan data. Data primer yang digunakan yaitu: (1) kedalaman freatik muka air tanah; (2) tekstur tanah; dan (3) kemiringan lereng. Kondisi kedalaman freatik air tanah diukur dengan pita ukur dari permukaan tanah hingga tinggi muka air tanah dengan satuan (m), tekstur tanah dilakukan dengan pengamatan langsung di lapangan, dan kondisi kemiringan lereng diukur dengan pengukuran alat ukur slope rangefinder dengan satuan pengukuran persen (\%) (BIG, 2018a). Parameter SINTACS dengan pendekatan data sekunder yaitu: (1) infiltrasi; (2) kondisi aerasi pada batuan; (3) litologi akuifer; dan (4) nilai konduktivitas hidrolik $(\mathrm{K}) /$ permeabilitas/kelulusan air pada batuan. Sumber data untuk penilaian penentuan kerentanan disajikan pada Tabel 1.

Tabel 1. Sumber Data Metode SINTACS

\begin{tabular}{lll}
\hline \multicolumn{1}{c}{ Parameter } & \multicolumn{1}{c}{ Data } & \multicolumn{1}{c}{ Sumber Data } \\
\hline (S) Soggiacenza (Depth of phreatic)) & Kedalaman muka air (m & BIG, 2018b); KESDM, \\
& & 2018 \\
(I) Infiltrazione (Infiltration) & Infiltrasi (mm/jam) & Hakim \& Suryono, 1994; \\
& & KESDM, 2012 \\
(N) Non Saturo (Aeration Condition) & Kondisi aerasi pada batuan & KESDM, 2012, 2015a \\
(T) Tipologia Della Copertura (Soil Texture) & Tekstur tanah & Sisultan, 2018; BIG, 2018b \\
(A) Acquifero (Aquifer media) & Media (litologi) akuifer & KESDM, 2015a, 2015b \\
& & \\
(C) Conducibilita (hydrolic conductivity) & (K) konduktivitas hidraulik & Hakim \& Suryono, 1994; \\
& /kelulusan (m/detik) & KESDM, 2012 \\
(S) Superficie topografica (topography slope & Kemiringan lereng (\%) & BIG, 2018a, 2018b \\
\hline
\end{tabular}

\section{Penilaian SINTACTS}

Penilaian zona kerentanan tanah terhadap pencemaran dilakukan dalam beberapa tahapan seperti pada diagram alir pada Gambar 3. Pendekatan untuk menentukan zona kerentanan air tanah secara spasial menggunakan metode SINTACS. Metode SINTACS merupakan salah satu pendekatan kerentanan air tanah yang didasarkan parameter hidrogeologi dengan pemberian nilai pada setiap parameter kerentanan dan nilai bobot (Aller et al., 1987; Civita \& De Maio, 2004; Linggasari et al., 2019). Parameter kerentanan menggunakan tujuh parameter, yaitu (S) Soggiacenza (Depth of phreatic) atau kedalaman muka air tanah, (I) Infiltrazione (Infiltration) atau kondisi Infiltrasi, (N) Non Saturo (Aeration Condition) atau kondisi aerasi pada batuan atau zona tak jenuh, (T) Tipologia Della Copertura (Soil Texture) atau Tektur tanah, (A) Acquifero (Aquifer media) atau material akuifer, (C) Conducibilita (hydrolic conductivity) atau (K) Konduktifitas hidrolik, dan (S) Superficie topografica (topography slope) atau kemiringan lereng dalam satuan \%. Klasifikasi kelas dan nilai pada setiap parameter SINTACS disajikan pada Tabel 2.

Pemberian nilai skor dan bobot didasarkan atas dampak yang memicu kondisi kerentanan air tanah (Purnama \& Cahyadi, 2019; Putranto et al., 2016). Penilaian skenario pembobotan disajikan pada Tabel 3. Nilai kelas kerentanan air tanah mengacu pada Civita, (1994) dengan pembagian empat kelas yang disajikan pada Tabel 4. Penilaian indeks kerentanan SINTACS diperoleh dari perhitungan linier ketujuh (7) parameter. 


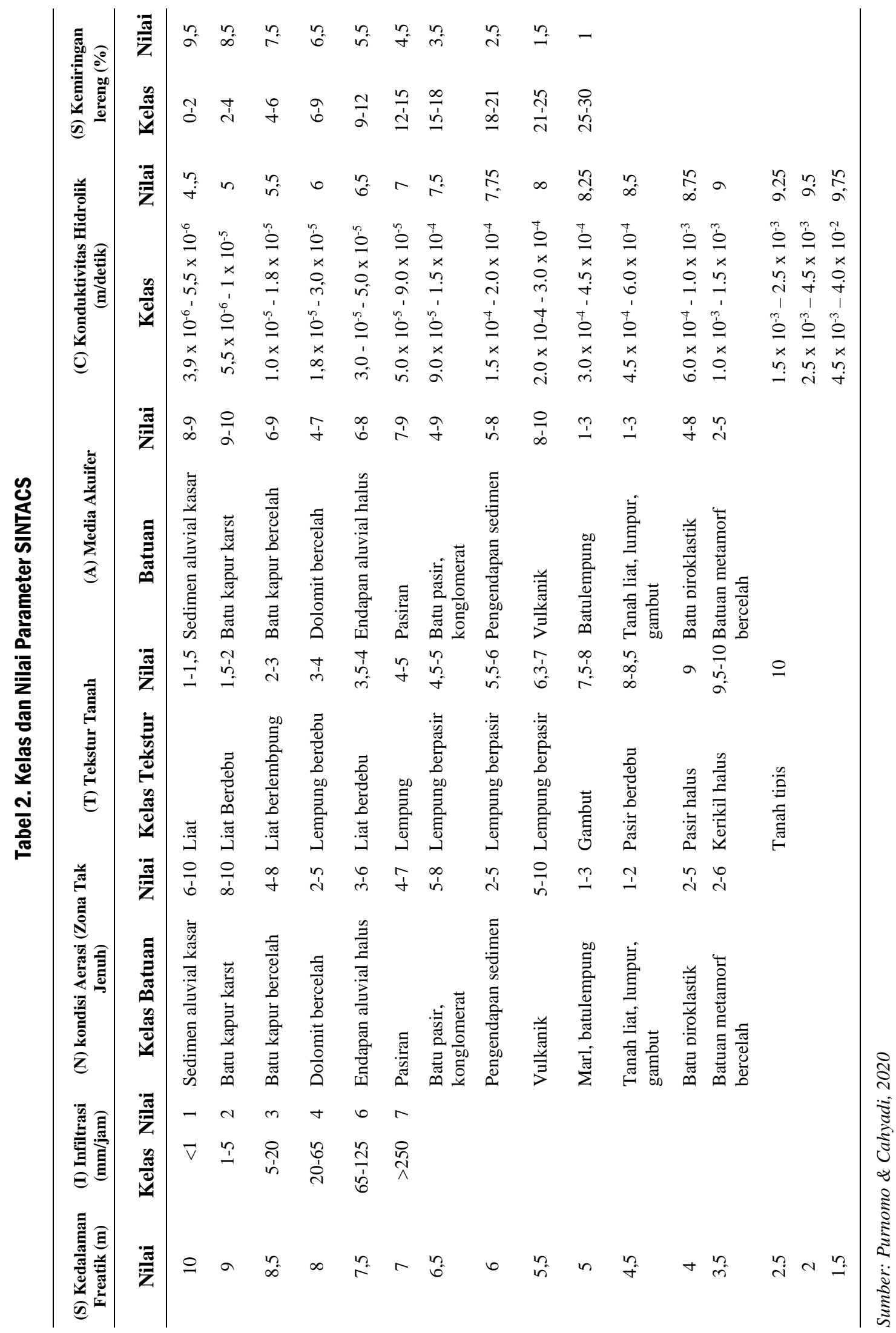


41 Penilaian Zona Kerentanan Air Tanah Terhadap Pencemaran dengan Metode SINTACS...

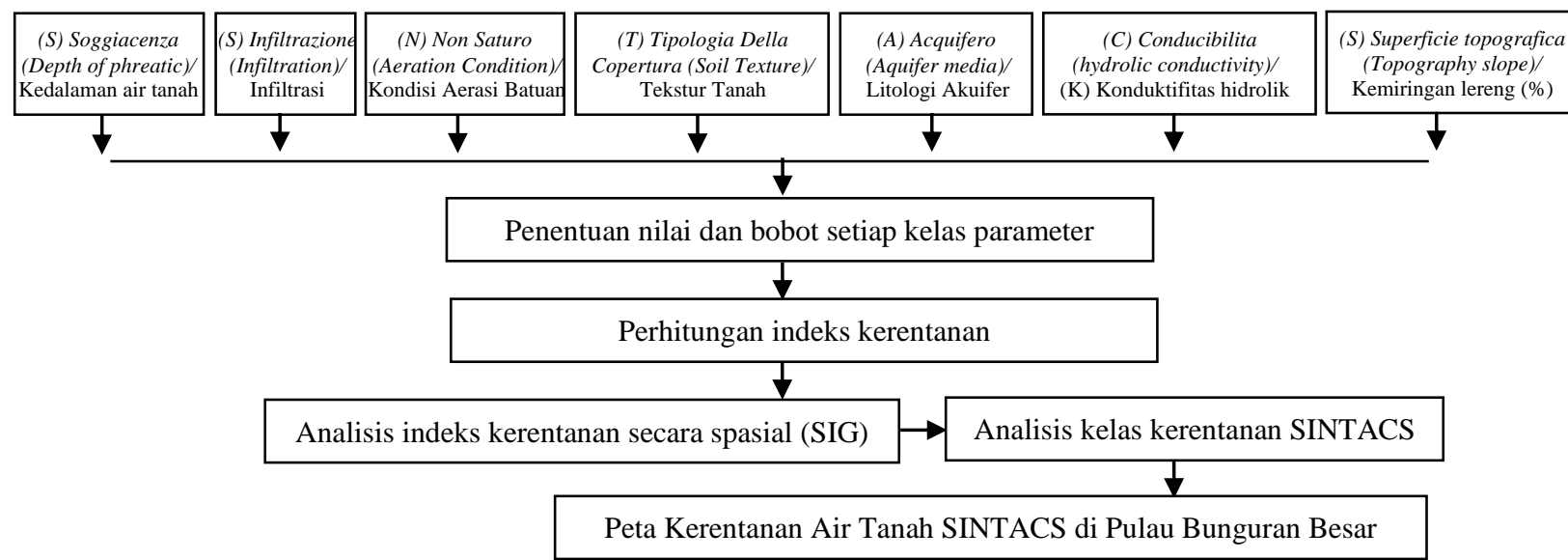

Gambar 3. Diagram Alir Perhitungan Kerentanan SINTACS

Pemberian bobot bertujuan untuk memberikan kondisi sebenarnya mengacu pada bobot skenario, seperti yang disajikan pada Tabel 3 (Civita, 1994; Civita \& De Maio, 2004). Rumus untuk nilai indeks kerentanan SINTACS diperoleh dari persamaan (1), sebagai berikut:

$$
\text { Kerentanan }=\mathrm{SrSw}+\mathrm{IrIw}+\mathrm{NrNw}+\mathrm{TrTw}+\mathrm{ArAw}+\mathrm{CrCw}+\mathrm{SrSw}
$$

dengan $\mathrm{r}=$ nilai masing-masing parameter (Tabel 2); dan $\mathrm{w}=$ bobot untuk masing-masing parameter (Tabel 3).

Tingkat kerentanan air tanah SINTACS mengacu klasifikasi dari Civita (1994), menjadi empat kelas kerentanan, yaitu rendah, sedang, tinggi dan sangat tinggi seperti yang disajikan pada Tabel 4.

Tabel 3. Bobot Skenario SINTACS

\begin{tabular}{lccccccc}
\hline \multicolumn{1}{c}{ Skenario Bobot } & S & I & N & T & A & C & S \\
\hline Dampak normal & 5 & 4 & 5 & 3 & 3 & 3 & 3 \\
Dampak relevan & 5 & 5 & 4 & 5 & 3 & 2 & 2 \\
Drainase dari jaringan permukaan/rembesan & 4 & 4 & 4 & 2 & 5 & 5 & 2 \\
Karst & 2 & 5 & 1 & 3 & 5 & 5 & 5 \\
Formasi batuan bercelah & 4 & 4 & 4 & 4 & 4 & 5 & 4 \\
Nitrat & 5 & 5 & 4 & 5 & 2 & 2 & 3 \\
\hline
\end{tabular}

Sumber:Civita \& De Maio, 2004; Civita, 1994

Tabel 4. Kriteria Kerentanan Indeks SINTACS

\begin{tabular}{|c|c|}
\hline Kerentanan & Indeks SINTACS \\
\hline Rendah & $<106$ \\
\hline Sedang & $106-186$ \\
\hline Tinggi & $187-210$ \\
\hline Sangat Tinggi & $>210$ \\
\hline
\end{tabular}




\section{Hasil dan Pembahasan}

\section{Kedalaman Muka Air Tanah (S)/Soggiacenza (Depth of phreatic)}

Kedalaman kondisi tinggi muka air (S) merupakan jarak permukaan tanah hingga permukaan air tanah. Kondisi ke dalam (jarak) tersebut memengaruhi potensi pencemaran apabila semakin dangkal dengan muka air tanah. Menurut BIG (2018b), Hakim \& Suryono (1994), dan KESDM (2012), menyebutkan bahwa litologi akuifer tersusun atas endapan lepas dan bersifat akuifer bebas, sehingga parameter menunjukkan kedalaman air tanah (freatik). Muka air tanah freatik merupakan kondisi muka air tanah pada akuifer tidak tertekan. Kondisi kedalaman air tanah terdistribusi dengan kedalaman 2-17 m di bawah permukaan tanah dengan nilai kedalaman tersebut 7 hingga 10 (Gambar 4).

Kondisi air tanah dangkal merupakan faktor pemicu terjadinya pencemaran, hal tersebut dipengaruhi oleh ketebalan batuan yang dangkal yang mempunyai korelasi dengan waktu yang cepat untuk meresap dan masuk ke dalam air tanah (akuifer) (Putranto et al., 2020). Pembentukan kelas kedalaman air tanah termasuk nilai yang rentan akan pencemaran, dengan kondisi rata-rata $2-5 \mathrm{~m}$ pada bagian tengah tengah dan pesisir, sedangkan pada daerah dengan morfologi perbukitan menunjukkan kedalaman yang semakin dalam hingga langka, yang memiliki faktor yang kecil atau tingkat kerentanan yang semakin rendah.

\section{Infiltrasi (I)/Infiltrazione (Infiltration)}

Kondisi infiltrasi (I) merupakan kemampuan dalam meloloskan air di dalam rongga batuan. Dalam hubungannya dengan pencemaran, kondisi infiltrasi merupakan parameter yang memengaruhi dalam menyerap dan mengalirkan sumber pencemar masuk ke dalam tanah hingga masuk ke akuifer. Semakin porus batuan yang dilalui maka mempunyai potensi kerentanan yang lebih tinggi. Satuan infiltrasi dinyatakan dalam $\mathrm{mm} / \mathrm{jam}$.

Penentuan nilai kondisi infiltasi diperoleh dari distribusi litologi akuifer menggunakan data geologi KESDM (2015a) kemudian menggunakan nilai korelasi laju infiltrasi menurut Asdak (2002) dan DPU (2006) dan kondisi pada batuan mengacu pada Todd \& Mays (2005). Berdasarkan nilai laju infitrasi tersebut diketahui bahwa empat karakteristik kondisi infiltrasi, yaitu pada material lanau memiliki laju infiltrasi $25 \mathrm{~mm} / \mathrm{jam}$ dan terdistribusi pada bagian tengah pulau dengan morfologi dataran dan perbukitan, material lempung dengan laju infiltrasi $0,004 \mathrm{~mm} /$ jam yang terdistibusi pada morfologi dataran dan daerah lembah dan rawa, material pasir halus memiliki laju infiltrasi $40 \mathrm{~mm} / \mathrm{jam}$, yang terdistribusi pada daerah pesisir dan sepadan pantai dan material pasir bergeluh memiliki laju infiltrasi sebesar $36 \mathrm{~mm} / \mathrm{jam}$ yang terdistribusi merata pada bagian tengah pulau. Secara umum kondisi dengan material pasiran memiliki laju infiltrasi yang sedang, berdasarkan nilai tersebut, kelas kerentanan pada parameter infiltrasi 1 hingga 4 pada material pasiran. Kondisi laju infiltrasi tersebut menurut DPU (2006) dan Putranto et al. (2016) termasuk parameter yang dominan memicu kecepatan pencemaran dengan nilai $36 \mathrm{~mm} / \mathrm{jam}$.

\section{Kondisi Aerasi (N)/Non Saturo (Aeration Condition)}

Non Saturo (Aeration Condition) (N) atau kondisi aerasi merupakan kondisi zona tak jenuh pada formasi batuan. Dalam kaitannya dengan kerentanan pencemaran, kondisi aerasi merupakan pendekatan parameter akuifer fisik batuan dari sifat hidrogeologi terhadap lapisan yang kedap air. Penilaian kondisi aerasi pada batuan diperoleh dari KESDM (2015a, 2015b). Berdasarkan analisis, diketahui di Pulau Bunguran Besar terdapat lima klasifikasi endapan alluvial dengan nilai 7 terdapat di bagian pesisir, pasiran dengan nilai 4 yang terdistribusi pada bagian pesisir, batu pasir dengan nilai 5 terdistribusi pada bagian tengah pada morfologi dataran, rombakan konglomerat dengan nilai 6 terdapat 


\section{Penilaian Zona Kerentanan Air Tanah Terhadap Pencemaran dengan Metode SINTACS...}

pada bagian utara dengan morfologi perbukitan dan rombakan kerakal sedang dengan nilai 3 (Gambar 4). Material rombakan lepas memiliki faktor yang dominan terhadap pencemaran seperti dalam penelitian Putranto \& Rüde (2016) disebutkan bahwa, material lepas dengan ukuran sedang hingga kasar memiliki dampak mempercepat kerentanan air tanah terhadap pencemaran.

\section{Tektur Tanah (T)/Tipologia Della Copertura (Soil Texture)}

Tekstur tanah (T) merupakan komposisi perbandingan material pasir, debu, dan tanah liat. Dalam hubungannya dengan kerentanan pencemaran, tekstur tanah yang lepaslepas memiliki potensi untuk mengalirkan sumber pencemar atau polutan meresap ke dalam tanah, sedangkan sebaliknya, tekstur tanah yang semakin mengandung lempung liat semakin lama mengalirkan sumber pencemar atau polutan. Penilaian tekstur tanah diperbarui dengan pengamatan di lapangan (BIG, 2018b). Tekstur tanah di Pulau Bunguran Besar terdiri atas tujuh kelas tekstur tanah, yaitu lempung yang terdapat di bagian utara dengan nilai 2, lempung bergeluh terdistribusi pada bagian timur bagian morfologi dengan kemiringan lereng miring degan nilai 3 , dan lempung lanau terdapat pada bagian pesisir di timur dengan nilai 4 (Gambar 4). Tekstur pasir bergeluh terdapat pada daerah cekungan (lembah) dan rawa, dengan nilai 5, lempung berpasir merupakan material yang mendominasi di bagian tengah pulau dengan nilai 7-8 dan pasir halus terdapat di persisir barat dan selatan dengan nilai 9 . Tekstur yang lepas-lepas memiliki korelasi dengan laju infiltrasi yang cepat meresap ke dalam tanah (Febriarta \& Larasati, 2020). Seperti hasil penelitian kerentanan dengan tekstur pasiran (material lepas-lepas) dalam Febriarta \& Vienastra (2020) dan Marfai et al. (2020) yang menyatakan material tersebut mempunyai potensi dalam mempercepat laju meresapnya air permukaan ke dalam tanah.

\section{Material (Litologi) Akuifer (A)/Acquifero (AquiferMedia)}

Parameter material akuifer (A) merupakan penyusun batuan atau litologi akuifer. Karakteristik media akuifer berpengaruh dalam pencampuran sumber pencemar atau polutan dengan air tanah. Litologi akuifer tersusun atas empat karakteristik akuifer, yaitu perselingan batu lanau malihan, rombakan granit, litologi kerakal dan aluvium endapan rawa perselingan batu lanau (KESDM, 2015a). Litologi akuifer perselingan batu lanau malih, tuf, dan rijang mempunyai potensi nilai 5 , yang terdistribusi pada bagian morfologi dataran pesisir di bagian timur dan perbukitan selatan. Litologi akuifer rombakan terdiri atas granit, putih kotor, kasar, prifiritik, holokristalin, kuarsa, ortoklas, plagioklas, biotit, dan muskovit mendominasi bagian tengah dan timur dengan nilai 6 . Material penyusun litologi akuifer kerakal, kerikil, pasir dan lumpur terdapat di bagian utara dan tengah pulau hingga dataran mempunyai nilai 7 dan material litologi akuifer aluvium endapan rawa terdiri atas material lepas berukuran kerikil, pasir, lempung, lumpur dan gambut yang terdapat hampir di seluruh pulau dan mendominasi penyusun akuifer yang memiliki nilai parameter kerentanan 8.

Semakin besar nilai parameter, maka mempunyai faktor pendorong kerentanan terhadap pencemaran. Kondisi tersebut seperti hasil penelitian Febriarta \& Vienastra (2020) menyebutkan bahwa litologi akuifer dengan media antar butir berupa pasiran memiliki faktor yang mendorong percepatan pencemaran. Marfai et al. (2020) menyebutkan bahwa media antar butir dengan ukuran sedang hingga kasar dapat mengalirkan sumber pencemar (polutan) dalam waktu yang singkat. Berdasarkan kondisi litologi akuifer hampir 40\% termasuk ke dalam tingkat kerentanan tinggi pada parameter akuifer. Secara umum kondisi penyusun litologi akuifer merupakan endapan dengan material lepas-lepas, material tersebut sangat mudah untuk meloloskan air tanah. 


\section{Konduktivitas Hidrolik (C)/Conducibilita (Hydrolic Conductivity) (K)}

Parameter konduktivitas hidrolik merupakan kondisi batuan dalam meloloskan air di dalam rongga batuan dengan satuan $\mathrm{m} /$ detik (BSN, 2005; Fetter, 2014). Penilaian konduktivitas hidrolik atau kelulusan air tanah (K), menggunaan data geologi yang diperoleh dari KESDM (2015a, 2015b), kemudian dikorelasikan penyusun batuannya dengan sifat konduktifitas mengacu dari nilai Todd \& Mays (2005). Berdasarkan analisis diketahui karakteristik nilai konduktivitas hidrolik terdapat empat kelas, yaitu pada batuan yang tersusun atas rombakan konglomerat, batu pasir dan batu lanau memiliki nilai 7, nilai konduktivitas hidrolik pada batuan mafik dan ultramafik memiliki nilai kerentanan 7,5 . Nilai konduktivitas hidrolik pada material aluvium endapan rawa terdiri atas material lepas berukuran kerikil, pasir, lempung, lumpur dan gambut bernilai 8 dan pada batuan penyusun terdiri atas selang seling batu pasir dan batu lanau memiliki nilai 8. Semakin cepat batuan meloloskan air tanah maka semakin cepat sistem akuifer mengalami pencemaran oleh sumber pencemar (Gunawan et al., 2013; Putranto et al., 2020). Berdasarkan karakteritik tersebut, material pasiran lepas-lepas dengan nilai dapat memicu kerentanan air tanah terhadap pencemaran yang terdapat pada bagian tengah pulau pada morfologi dataran dan bagian pesisir.
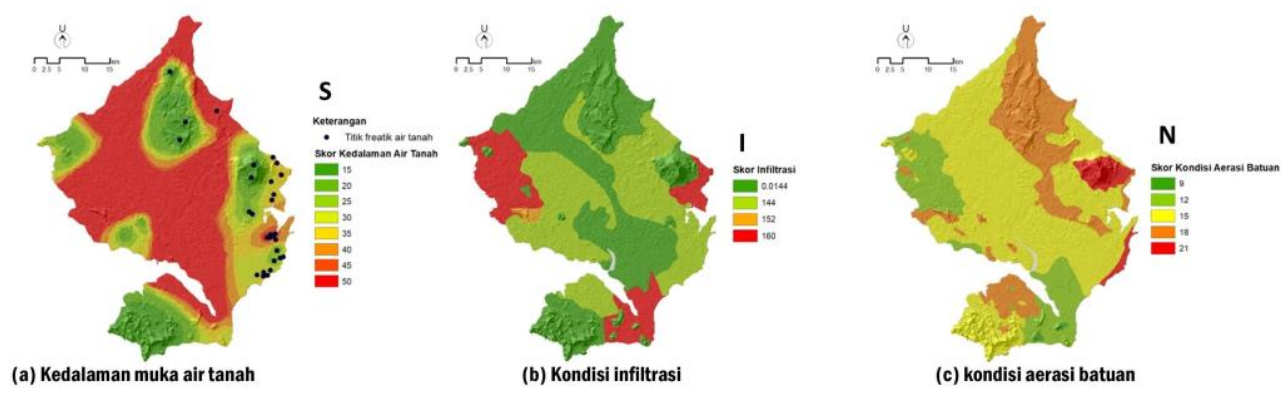

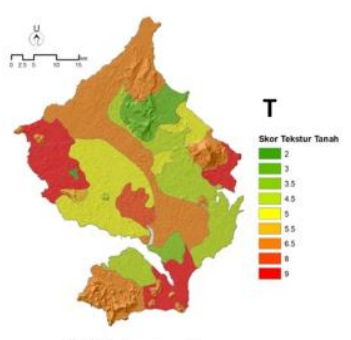

(d) Tekstur tanah

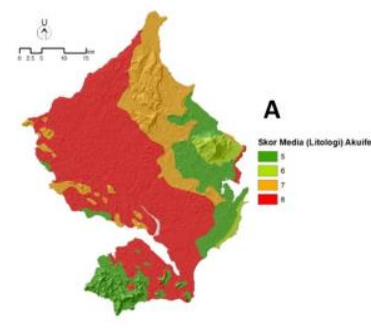

(e) media/litologi akuifer

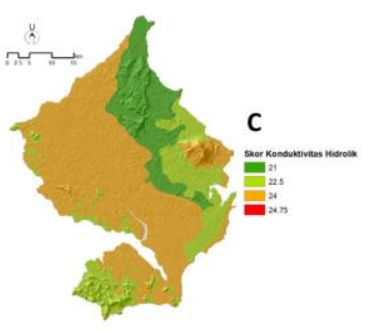

(f) konduktivitas hidrolik

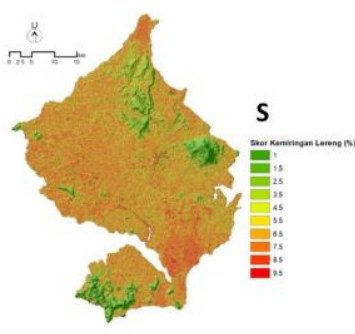

(g) kemiringan lereng

\section{Gambar 4. Parameter Kerentanan SINTACS}

\section{Kemiringan Lereng(S) / Superficie Topografica (Topography Slope)}

Parameter kemiringan lereng (S) dalam kerentanan pencemaran dapat memicu kondisi persentase (\%) kondisi lereng. Kemiringan lereng berpengaruh dalam mengalirkan aliran permukaan. Kondisi yang semakin datar dapat memicu kerentanan pencemaran, sehingga pada daerah tersebut dapat menjadi tempat berkumpulnya aliran permukaan dan menjadi genangan. Keterdapatan genangan tersebut dapat memicu masuknya sumber pencemar atau polutan masuk ke dalam air tanah (akuifer). Kondisi kemiringan lereng diperoleh dari ekstrasi data elevasi digital (digital elevation model nasional/DEMNas) dari BIG (2018a) dengan resolusi $30 \mathrm{~m}$. Berdasarkan analisis tersebut diketahui kondisi kemiringan kereng 0-27\% sehingga nilai kemiringan lereng memiliki rentang 1-9,5. Secara 
umum kondisi di Pulau Bunguran Besar memiliki morfologi datar hingga 0\% hingga miring $6 \%$. Daerah dengan kemiringan lereng yang relatif miring tersebut terdistribusi merata, sehingga memiliki kerentanan sedang hingga tinggi dari parameter kemiringan lereng. Semakin landai topografi maka memiliki potensi menjadi tempat genangan atau berkumpulnya air dan jika berlangsung dalam waktu yang lama dan berulang maka dapat menjadi zona masuknya sumber pencemar (polutan) ke dalam sistem akuifer (Putranto et al., 2016). Sedangkan pada kondisi kemiringan yang semakin miring memiliki kerentanan yang kecil, hal tersebut dipengaruhi oleh gradien atau nilai kemiringan yang semakin curam akan mengalirkan air dan tidak terjadi genangan dan tidak terjadi proses peresapan air permukaan ke dalam tanah (Thapa et al., 2018).

\section{Zona Kerentanan Air Tanah Terhadap Pencemaran}

Zona kerentanan merupakan daerah yang menunjukkan nilai indeks kerentanan SINTACS yang kemudian diklasifikasikan ke dalam tingkat kerentanan pencemaran (Gunawan et al., 2013). Nilai indeks kerentanan SINTACS diperoleh dari perhitungan rumus persamaan (1). Berdasarkan perhitungan indeks kerentanan, diketahui nilai indeks kerentanan di Pulau Bunguran Besar memiliki rentang 89 - 230. Berdasarkan nilai indeks kerentanan tersebut, diperoleh empat tingkat kerentanan air tanah, yaitu kerentanan rendah seluas $486 \mathrm{~km}^{2}$ atau seluas $28 \%$, kerentanan sedang seluas $343,8 \mathrm{~km}^{2}$, kerentanan tinggi seluas $0,7 \mathrm{~km}^{2}$ atau seluas $0,04 \%$ dan kerentanan sangat tinggi dengan luas wilayah $898,7 \mathrm{~km}^{2}$ atau seluas $52 \%$ (Gambar $5 \mathrm{a}$ ).

Secara keruangan (spasial) per wilayah administrasi, diketahui di Kecamatan Bunguran Barat memiliki potensi tingkat kerentanan air tanah rendah seluas $205,4 \mathrm{~km}^{2}$ atau seluas $11,7 \%$, kerentanan sedang $300,3 \mathrm{~km}^{2}$ atau seluas $2,4 \%$, kerentanan tinggi seluas 0,1 $\mathrm{km}^{2}$ atau seluas $0,1 \%$ dan kerentanan sangat tinggi dengan luas $488,2 \mathrm{~km}^{2}$ atau seluas $28,1 \%$, seperti yang disajikan pada Gambar $5 \mathrm{~b}$. Sedangkan kerentanan air tanah terhadap pencemaran di Kecamatan Bunguran Timur potensi tingkat kerentanan rendah seluas 280,6 $\mathrm{km}^{2}$ atau $16,1 \%$, kerentanan sedang $43 \mathrm{~km}^{2}$ atau seluas $17,2 \%$, kerentanan tinggi dengan luas $0,6 \mathrm{~km}^{2}$ atau seluas $0,5 \%$ dan kerentanan sangat tinggi dengan luas $425 \mathrm{~km}^{2}$ atau seluas $24,4 \%$.

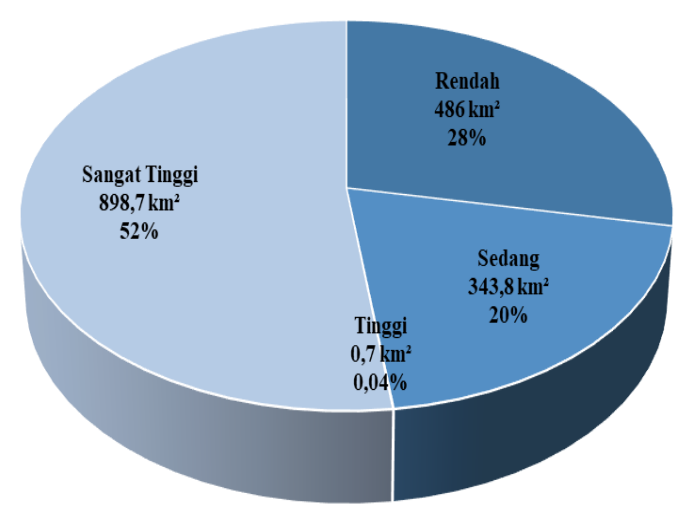

(a)

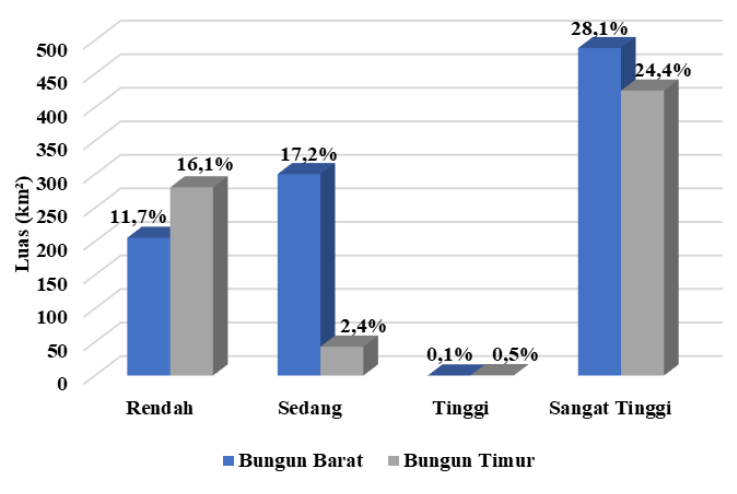

(b)

\section{Gambar 5. Luas Tingkat Kerentanan, (a) Luas Kerentanan dan (b) Luas Kerentanan per Kecamatan}

Kerentanan air tanah terhadap pencemaran rendah, dicirikan dengan kondisi freatik air tanah yang dalam dengan kondisi penyusun batuan yang didominasi dengan lempung perselingan pasir halus pada kondisi daerah kemiringan lereng yang curam. Kerentanan air 
tanah sedang dicirikan dengan kondisi kedalaman muka air tanah (freatik) 7-10 m di bawah permukaan tanah dengan kondisi infiltrasi rata-rata $1-15 \mathrm{~mm} / \mathrm{jam}$, dengan penyusun formasi batuan yang didominasi oleh endapan pasiran halus, rombakan batu mafikultramafik dan berada pada kondisi morfologi agak curam. Kerentanan sedang dicirikan dengan kondisi kedalaman air tanah freatik 5-15 m di bawah permukaan tanah dengan kondisi infiltrasi berkisar 1-15 $\mathrm{mm} / \mathrm{jam}$ dan penyusun material batuan berupa endapan lepas-lepas. Kerentanan air tanah terhadap pencemaran tinggi dicirikan dengan kondisi kedalaman muka air tanah 4-7 $\mathrm{m}$ di bawah permukaan tanah dengan kondisi laju infiltrasi 15-15 mm/jam dengan penyusun formasi batuan endapan sedimen lepas-lepas, batulempung dan lanau pada daerah dengan kemiringan lereng agak miring hingga agak curam.

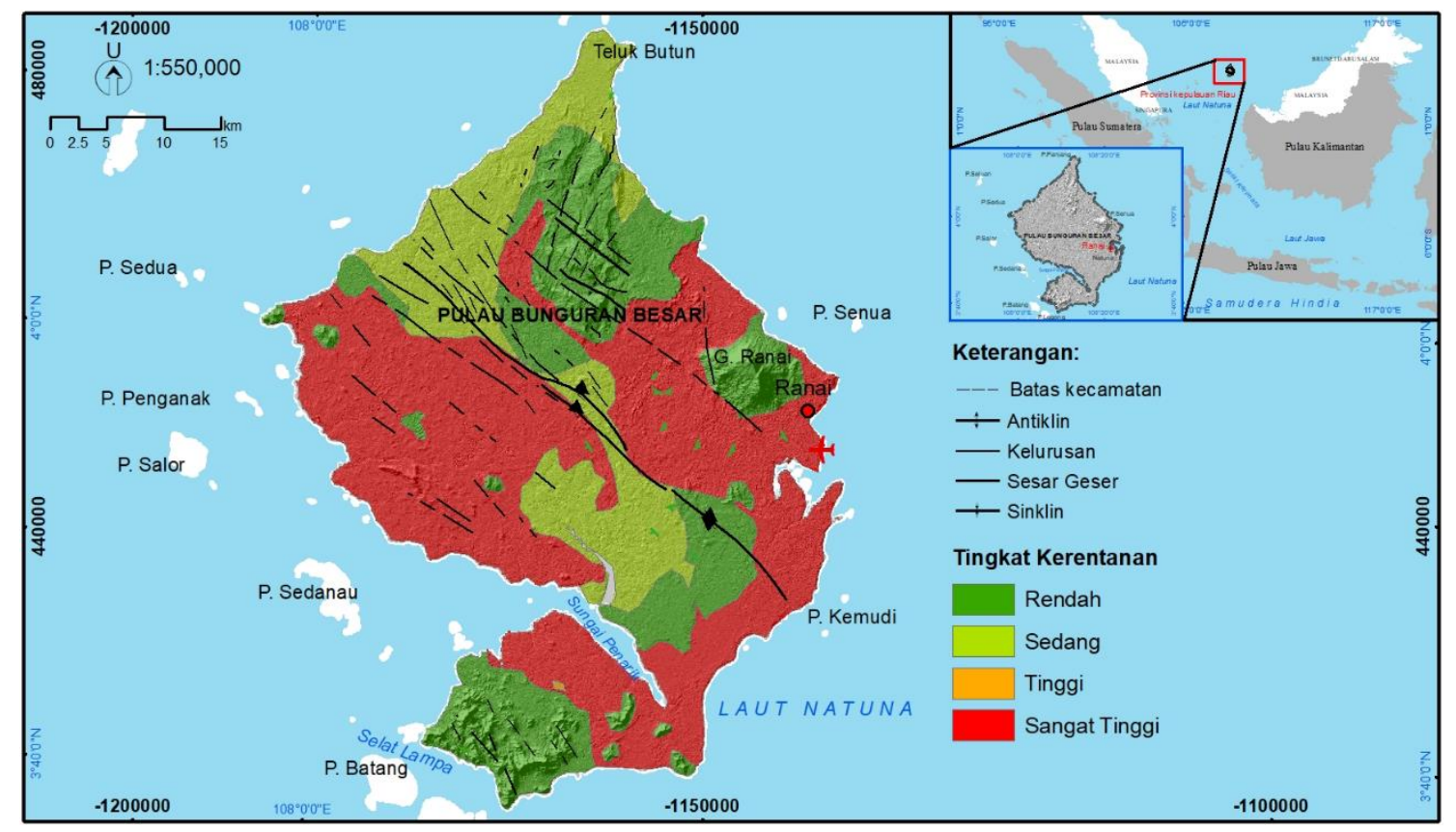

\section{Gambar 6. Kerentanan Air Tanah terhadap Pencemaran}

Kerentanan air tanah terhadap pencemaran sangat tinggi dicirikan dengan kedalaman muka air tanah yang dangkal 0-4 m dibawah permukaan tanah dengan kondisi laju infiltrasi $36 \mathrm{~mm} / \mathrm{jam}$ pada formasi penysusun batuan yang sangat porus, yaitu sedimen alluvial kasar, rombakan batu mafik-ultramafik dan batupasir kasar, dengan kondisi morfologi yang datar dengan kemiringan lereng datar hingga landai. Berdasarkan perhitungan dan analisis, diketahui secara umum tingkat kerentanan air tanah terhadap pencemaran masuk kedalam tingkat sangat tinggi dengan distribusi $52 \%$ dari luas wilayah (Gambar 6).

\section{Kesimpulan}

Metode SINTACS dapat menyajikan nilai indeks kerentanan dengan rentang nilai yang panjang, sehingga dapat diidentifikasi zona kerentanan lebih detail. Berdasarkan hasil perhitungan diketahui zona dengan kerentanan tinggi terjadi interaksi kondisi permukaan dan parameter akuifer bebas. Terdapat kekurangan dalam penilaian SINTACS, yaitu 


\section{Penilaian Zona Kerentanan Air Tanah Terhadap Pencemaran dengan Metode SINTACS...}

diperlukannya data yang cukup banyak untuk menghitung nilai kerentanan. Parameter SINTACS hanya mempertimbangkan sifat hidrogeologi (parameter akuifer) secara statis belum mempertimbangkan imbuhan air yaitu air hujan, yang memiliki faktor dalam pengenceran sumber pencemar (polutan) dan mempercepat laju pencemaran. Saran untuk pengelolaan sumber air pada zona kerentanan rendah adalah dengan edukasi atau pegenalan masyarakat terhadap informasi pengelolaan sampah, limbah dan penampungan limbah secara komunal. Kerentanan air tanah sedang memiliki potensi pencemaran dari sumber pencemar (polutan) dalam waktu yang berlangsung lama. Saran untuk pengelolaan dan pemantuan zona kerentanan sedang adalah dengan pemantauan kualitas air tanah. Kerentanan air tanah terhadap pencemaran tinggi mempunyai potensi pencemaran sebesar setengah dari sumber pencemar (polutan), saran untuk pengelolaan air adalah dengan pemantauan air tanah dengan uji standar baku mutu air minum. Kerentanan sangat tinggi mempunyai potensi pencemaran seluruh dari sumber pencemar (polutan) dapat masuk hingga ke dalam sistem air tanah (akuifer). Saran untuk pengelolaan air adalah dengan pembutan sumur pantau pada daerah padat penduduk dan sosialisasi pemahaman pengelolaan limbah rumah tangga, pemantauan uji kimia baku mutu air minum, hingga dengan penyususnan pengelolaan dan perlindungan menjadi peraturah daerah (PERDA) dalam pengelolaan sampah dan limbah.

\section{Ucapan Terima Kasih}

Artikel ini merupakan salah satu bagian dari analisis lanjut dari penelitian terkait penyusunan Rencana Detail Tata Ruang (RDTR) Wilayah Pusat Kegiatan Strategis Nasional (PKSN) di Kepulauan Anambas, Kabupaten Kepulauan Riau yang difasilitasi oleh Badan Informasi Geospasial (BIG) Republik Indonesia. Ucapan terima kasih ditujukan kepada Pusat Pemetaan Tata Ruang dan Atlas, Badan Informasi Geospasial (BIG) Republik Indonesia yang telah memfasilitasi dan mendukung penelitian ini.

\section{Daftar Pustaka}

Aller, L., Bennett, T., Lehr, J. H., \& Petty, R. J. (1987). DRASTIC: a standardized system for evaluating ground water pollution potential using hydrogeologic settings. United States: Office of Research and Development. Environmental Protection Agency USA.

Appelo, C. A. ., \& Postma, D. (2007). Geochemis- try, groundwater and pollution. Amsterdam: A.A. Balkema Publishers.

Asdak, C. (2002). Hidrologi dan pengelolaan daerah aliran sungai. Yogyakarta: Gadjah Mada University Press.

Badan Informasi Geospasial (BIG). (2018a). DEMNAS 1219-6 s/d DEMNAS 1320-21. Indonesia: Badan Informasi Geospasial.

Badan Informasi Geospasial (BIG). (2018b). Penyusunan peta rencana detail tata ruang (RDTR) wilayah pusat kawasan strategis nasional (PKSN) perbatasan negara (Laporan Ak; D. B. IGT, Ed.). Bogor: Badan Informasi Geospasial.

Badan Standardisasi Nasional (BSN). (2002). Penyusunan neraca sumber daya - Bagian 1: Sumber daya air spasial SNI 19-6728.1-2002. In Badan Standardisasi Nasional (BSN). Jakarta, Indonesia: Badan Standardisasi Nasional (BSN).

Badan Standardisasi Nasional (BSN). (2005). Penyelidikan potensi air tanah skala 1: 100 . 000 atau lebih besar SNI 13-7121-2005. Jakarta, Indonesia: Badan Standardisasi Nasional (BSN).

Cahyadi, A. (2019). Analisis kerentanan airtanah terhadap pencemaran di Pulau Koral sangat kecil dengan menggunakan metode GOD. Jurnal Geografi, 16(1), 48-53. doi:10.15294/jg.v16i1.18411.

Civita, M, \& De Maio, M. (2004). Assessing and mapping groundwater vulnerability to contamination: The Italian "combined” approach. Geofisica Internacional, 2(1), 14-28. 
Civita, M. (1994). La carte della vulnerabilita'degli acquiferi all'inquiamento: Teoria e Pratica/Pollution vulnerability maps of aquifers: theory and practice. Bologne. Italie: Pitagora editrice.

Departemen Pekerjaan Umum (DPU). (2006). Standar kebutuhan air rumah tangga. Jakarta, Indonesia: Ditjen Cipta Karya.

Devianto, L. A., Lusiana, N., \& Ramdani, F. (2019). Analisis kerentanan pencemaran air tanah di Kota Batu menggunakan analisis multikriteria spasial dengan indeks DRASTIC. Jurnal Wilayah dan Lingkungan, 72), 90-104. doi:10.14710/jwl.7.2.90-104.

Febriarta, E., Haryono, E., \& Adji, T. N. (2015). Aplikasi teknologi isotop alam untuk menentukan asal usul airtanah pesisir. Seminar Nasional Pengelolaan Pesisir dan Daerah Aliran Sungai Ke-1, 1, 100-105. doi:10.17605/osf.io/7a5m6.

Febriarta, E., \& Larasati, A. (2020). Karakteristik akuifer air tanah dangkal di endapan muda merapi Yogyakarta. Jurnal Sains dan Teknologi Lingkungan, 12(2), 84-99. doi:10.20885/jstl.vol12.iss2.art1.

Febriarta, E., \& Oktama, R. (2020). Pemetaan daya dukung lingkungan berbasis jasa ekosistem penyedia pangan dan air bersih di Kota Pekalongan. Jurnal Ilmu Lingkungan, 18(2), 283-289. doi:10.14710/jil.18.2.283289.

Febriarta, E., Prabawa, B. A., \& Rosaji, F. S. C. (2018). Sumberdaya air di Pulau Pelapis Kepulauan Karimata, Kabupaten Kayong Utara, Kalimantan Barat. Seminar Nasional IV Pengelolaan Pesisir dan Daerah Aliran Sungai, 4, 174-181. doi:10.17605/osf.io/v6nx8.

Febriarta, E., Suswanti, S., \& Noviandaru, S. (2020). Interpretasi electrical resistivity tomography (ERT) untuk pendugaan air tanah dangkal pada formasi gunungapi muda. Jurnal Nasional Teknologi Terapan (JNTT), 3(1), 33-46. doi:10.22146/jntt.56617.

Febriarta, E., \& Vienastra, S. (2020). Penentuan zona kerentanan airtanah metode simple vertical vulnerability di Pulau Yeben. Jurnal Swarnabhumi: Jurnal Geografi dan Pembelajaran Geografi, 5(2), 58-66. doi:10.31851/swarnabhumi.v5i2.4431.

Ferreira, J. P., Lobo, Oliveira, \& Manuel, M. (2004). Groundwater vulnerability assessment in Portugal. Geofisica International, 4, 541-550.

Fetter, C. W. (2014). Applied hydrogeology. England: Pearson New Internasional Edition.

Foster, S. S. . (1987). Fundamental concepts in aquifer vulnerability, pollution risk and protection strategy, vulnerability of soil and groundwater to pollutants. TNO Commission on Hydro Res, 38, 69-86.

Gunawan, W. A. F., Sisinggih, D., \& Dermawan, V. (2013). Studi kerentanan air tanah terhadap kontaminan di cekungan airtanah negara Kabupaten Jembrana Provinsi Bali. Jurnal Teknik Pengairan Universitas Brawijaya, 4(2).

Hakim, A. ., \& Suryono, N. (1994). Peta geologi lembar Teluk Butun dan Ranai, Sumatera. Bandung: Pusat Penelitian dan Pengembangan Geologi.

Harter, T., \& Walker, L. G. (2001). Assessing vulnerability of groundwater (L. Rollins, Ed.). California. Retrieved from https://www.scribd.com/document/269083852/Assessing-Vulnerability-of-Ground-Water.

Kementerian Energi dan Sumber Daya Mineral (KESDM). (2012). Geologi. Jakarta: Kementerian Energi dan Sumber Daya Mineral.

Kementerian Energi dan Sumber Daya Mineral (KESDM). (2015a). Litologi akuifer. Jakarta: Kementerian Energi dan Sumber Daya Mineral.

Kementerian Energi dan Sumber Daya Mineral (KESDM). (2015b). Produktivitas akuifer. Jakarta: Kementerian Energi dan Sumber Daya Mineral.

Kementerian Energi dan Sumber Daya Mineral (KESDM). (2018). Cekungan air tanah (CAT). Jakarta: Kementerian Energi dan Sumber Daya Mineral.

Lathamani, R., Janardhana, M. R., Mahalingam, B., \& Suresha, S. (2015). Evaluation of aquifer vulnerability using drastic model and GIS: A case study of Mysore City, Karnataka, India. Aquatic Procedia, 4, 10311038. doi:10.1016/j.aqpro.2015.02.130.

Linggasari, S., Cahyadi, T. ., \& Ernawati, R. (2019). Overview metode perhitungan kerentanan airtanah terhadap rencana penambangan. Prosiding Nasional Rekayasa Teknologi Industri dan Informasi XIV Tahun 2019 (ReTII)., 14, 123-129.

Marfai, M. A., Febriarta, E., Hizbaron, D. R., \& Larasati, A. (2020). Kajian spasial multi kriteria DRASTIC 


\section{Penilaian Zona Kerentanan Air Tanah Terhadap Pencemaran dengan Metode SINTACS...}

kerentanan air tanah pesisir akuifer batugamping di Tanjungbumi Madura. Jurnal Ilmu Lingkungan, 18(3), 476-487. doi:10.14710/jil.18.3.476-487.

Pemerintah Republik Indonesia. (2017). Peraturan Menteri Energi dan Sumber daya Mineral No.2 Tahun 2017 tentang cekungan air tanah di Indonesia. Jakarta, Indonesia: Menteri Energi dan Sumber Daya Mineral.

Pemerintah Republik Indonesia. (2020). Peraturan Presiden Republik Indonesia Nomor 43 Tahun 2020 tentang rencana tata ruang kawasan perbatasan negara di Provinsi Riau dan Provinsi Kepulauan Riau. Jakarta, Indonesia: Presiden Republik Indonesia.

Purnama, S., \& Cahyadi, A. (2019). Groundwater vulnerability to pollution in Kasihan District, Bantul Regency, Indonesia. Forum Geografi, 33(2), 140-152. doi:10.23917/forgeo.v33i2.7672.

Purnama, S., Tivianton, T. A., Cahyadi, A., \& Febriarta, E. (2019). Kajian daerah imbuhan airtanah di Kabupaten Ngawi. Jurnal Geografi, 16(1), 54-59. doi:10.15294/jg.v16i1.18358.

Putranto, T. T., \& Rüde, T. (2016). Hydrogeological model of an urban city in a Coastal Area, Case study: Semarang, Indonesia. Indonesian Journal on Geoscience, 3(1), 17-27. doi:10.17014/ijog.3.1.17-27.

Putranto, T. T., Widiarso, D., \& Yuslihanu, F. (2016). Studi kerentanan air tanah terhadap kontaminan menggunakan metode Drastic di Kota Pekalongan. Teknik, 371), 26-31. doi:10.14710/teknik.v37i1.9637.

Putranto, T. T., Winarno, T., \& Susanta, A. P. A. (2020). Risk assessment of groundwater abstraction vulnerability using spatial analysis: Case study at Salatiga groundwater basin, Indonesia. Indonesian Journal on Geoscience, 72), 215-224. doi:10.17014/ijog.7.2.215-224.

Singhal, B. B., \& Gupta, R. (2010). Applied hydogeology of fracture rock. London: Springer Dordrecht Heidelberg London.

Sisultan. (2018). Peta Tanah Skala 1:50.000. Jakarta: Kementerian Pertanian.

Sugianti, K., Mulyadi, D., \& Maria, R. (2016). Analisis kerentanan pencemaran air tanah dengan pendekatan metode drastic di Bandung Selatan. Jurnal Lingkungan dan Bencana Geologi, 71), 19-33. doi:10.34126/jlbg.v7i1.91.

Thapa, R., Gupta, S., Guin, S., \& Kaur, H. (2018). Sensitivity analysis and mapping the potential groundwater vurnerability zones in Birbhum district, India: A comparative approach between vurnerability models. Water Science, 32(1), 44-66. doi:10.1016/j.wsj.2018.02.003.

Todd, D. K., \& Mays, L. W. (2005). Groundwater hydrology (3rd ed.). Denver: John Wiley \& Sons, Inc.

Vienastra, S., \& Febriarta, E. (2018). Karakteristik airtanah di Pulau Yeben, Kabupaten Raja Ampat, Papua Barat. Prosiding Pertemuan Ilmiah Tahunan Ke-3 Perhimpunan Ahli Airtanah Indonesia, 3(November), 108113. doi:10.17605/OSF.IO/EZHDT.

Voutchkova, D. D., Schullehner, J., Rasmussen, P., \& Hansen, B. (2021). A high-resolution nitrate vulnerability assessment of sandy aquifers (DRASTIC-N). Journal of Environmental Management, 277, 111330. doi:10.1016/j.jenvman.2020.111330.

Vrba, J., \& Zaporozec, A. (1994). Guidebook on mapping groundwater vulnerability. Hannover: International Association of Hydrogeologist. 